https://doi.org/10.18485/iipe_60nam.2021.ch13

\title{
YUGOSLAVIA AND THE NON-ALIGNED MOVEMENT
}

\author{
Dragan BOGETIĆ ${ }^{1}$
}

\begin{abstract}
The present paper analyses the process of shaping the policy of non-alignment, from its first manifestations in the form of individual foreign policy orientation of individual states to the creation of the first outlines of a broad movement that enabled joint organised and continuous action of these non-aligned states in the United Nations and wider international relations. A special place in this analysis is dedicated to socialist Yugoslavia, which played a key role in the formation of the NonAligned Movement, in its development, but also its constant confrontation with serious temptations and overcoming frequent crises that called into question its continued survival. Based on the analysis of relevant archival material, the author came to the conclusion that the Non-Aligned Movement would never have achieved its global role in the Cold War polarized world without the continuous, skillfully designed and offensive performance of Yugoslav diplomacy and Yugoslav leader Josip Broz Tito. On the other hand, socialist Yugoslavia could never have played such a significant role in that bloc-divided world without the constant, wellorganised and efficient action of this broad and democratically organised Movement. Compared to other members of the Non-Aligned Movement, which undoubtedly could pursue their foreign policy interests within the existing regional Afro-Asian and Latin American organisations, Yugoslavia could ensure the stability of its internal order and national independence only through alliance and joint action within such a neutral international association. Hence, it is no wonder that Tito built a new world without which he himself could not survive, just as, after all, that world in its original version could not survive without Tito.
\end{abstract}

Key words: Non-alignment, Yugoslavia, blocs, Third World, decolonisation, United Nations.

\footnotetext{
${ }^{1}$ Professorial Fellow, Institute for Recent History of Serbia, Belgrade, Serbia. E-mail: dbogetić@gmail.com
} 


\section{Introduction}

At the beginning of the 90 s of the last century, and after the disintegration of the Yugoslav state, the domestic public often asked questions: Why did Yugoslavia distance itself from Europe and why did it become attached to distant and foreign civilizations? Why were Afro-Asian and Latin American countries closer to Yugoslavia than the countries from its immediate neighbourhood? Why did Yugoslavia tie its destiny to the destiny of the Non-Aligned Movement? This Yugoslav foreign policy has often been criticized as a kind of "escape from Europe". Such perceptions became especially relevant at the time of the dissolution of the Warsaw Pact and the end of the Cold War when the basic preconditions for the further survival of the bipolar world were finally eliminated. The Non-Aligned Movement represented a kind of antipode and alternative to such a world, in which non-aligned countries saw the main source and main generator of all international crises and all serious problems in the world. In that sense, the collapse of the bipolar system, in a way, has made meaningless the key political premises on which the platform of global action and the strategy of the Non-Aligned Movement were based. But, also, with the overthrow of that system, in a way, the foundations on which socialist Yugoslavia rested were destroyed, whose international prestige and solid international position arose precisely from that anti-bloc non-aligned policy. From today's perspective, it seems that the biggest loser of the end of the Cold War was Yugoslavia - the country that advocated the most for a world free of bloc confrontation and Cold War tensions. The entire Yugoslav diplomatic history was marked by constant foreign policy wandering and manoeuvring between the East and West. Its ideology did not allow it to join the West, and billions of dollars and Western economic concessions did not allow it to join the East. Yugoslavia found a way out of such an intricate cycle in something that is neither East nor West - in the policy of non-alignment.

\section{The emergence of the Yugoslav foreign policy strategy of non-alignment}

With the formation of Yugoslavia's new international strategy in the mid-1950s, a process of changing its foreign policy took place. This process included three directions: normalization of relations with the East (primarily with the Soviet Union), a continuation of cooperation with the West and opening to the newly liberated Afro-Asian states. Of course, the realization of the key political premises of this third direction was of special importance. 
The stabilization of internal affairs and the strengthening of Yugoslavia's international position directly depended on the outcome of its efforts to form a movement of states pursuing similar foreign policies. There was an unbreakable connection between these two phenomena (consolidation of Tito's regime and the formation of the Non-Aligned Movement). These phenomena ultimately conditioned each other. The Non-Aligned Movement enabled Tito's Yugoslavia to play the role of an important global player, and Tito's Yugoslavia provided the Non-Aligned Movement with a relatively influential and important factor in resolving numerous crises in the world and alleviating antagonisms between two opposing Cold War blocs. The Yugoslav insistence on the formation of the Non-Aligned Movement stemmed from a very simple foreign policy calculation led by Tito and his associates at a time when they faced the real danger of Yugoslavia being exposed to general international isolation. In such conditions, it was certainly necessary to secure the support of some powerful international factor when it was obviously necessary to seek somewhere outside the European space. According to the logic of the elimination system, such a factor could only be the newly liberated Afro-Asian states. Admittedly, the newly independent states alone could not play a significant role in international relations. But united in a broader international association, these countries could potentially become a significant international factor capable of parrying successfully bloc politics. Tito's commitment to non-alignment was a reflection of Tito's pragmatism and his extremely rational view of political reality. In the current situation, Tito did not see another political way out. For him, non-alignment was a kind of extortion and the only acceptable solution, but not a political alternative that generally fit into the ideological postulates he was guided by. He hated the very term "non-alignment" and did not use it at all during the first two summits of non-aligned countries in Belgrade and Cairo. He explained the inadequacy of the term, which was used by the leaders of all other nonaligned countries, by saying that it implied "equal distance" to the conflicting blocs and thus equated the policies of the socialist and capitalist countries, which, according to Yugoslav communists, led to suppressing and eliminating the "class aspect" within the Yugoslav foreign policy orientation. On the other hand, the term "non-alignment" seemed inadequate in Yugoslav political doctrine also because it implied a passive and neutral attitude towards dangerous crisis hotspots in the world.

The Yugoslav political doctrine considered that any passivity would be "immoral" and "short-sighted", and that the main determinant of nonaligned policy must be strong support for those forces that fight for world 
peace and oppose the forces that threaten that peace. In practice, the mentioned reasoning was usually reduced to unreserved support for the bloc of pro-Soviet states and permanent condemnation of the policy of the Western powers. Such an approach was expressed until the moment when the Summit of Non-Aligned Countries in Lusaka (Zambia), in September 1970, finally provided the political and normative conditions for the formation of the Non-Aligned Movement. From that moment on, Yugoslavia became the main advocate of a strictly balanced attitude towards the countries of the East and the West. ${ }^{2}$ (Bogetić, 2012, pp. 33-34; 2019, pp. 81-82; Dimić, 2014, p. 129-131; Petković, 1985, pp. 31-35). Hence, for Yugoslavia, there were no more dilemmas about the necessity of realizing the stated political projection on the formation of a broad international association of non-aligned states. Potential members of such an association and desirable future allies from Asia and Africa, however, did not show excessive willingness or interest in following Yugoslavia in its ambitious efforts.

\section{Foreign policy orientation on the non-alignment of Asian and African countries}

Although they unwaveringly followed a non-aligned orientation in international relations, the most influential Afro-Asian statesmen and leaders of India, Egypt, Indonesia and Ceylon - Jawarharlal Nehru, Gamal Abdel Nasser, Ahmed Sukarno and Solomon Bandaranaike - did not show much interest in working together. Thus, for example, Indian Prime Minister Nehru, who was the leader of an important regional power that enjoyed a

\footnotetext{
${ }^{2}$ Until then, Tito used the terms: "coexistence", "non-involvement", "noncommitted politics", "coexistence politics", "non-aligned politics", and called countries that pursued such foreign policy "non-aligned", "non-aligned" or "nonaligned" countries. According to his own account, Tito first heard of the term "nonalignment" from Nehru. The meaning of this expression was contained in the policy of equidistance, that is, avoiding any moves that would disrupt a balanced relationship with the confronted blocs. Therefore, Nehru's policy, as well as the very content of the term "non-alignment", was seen by Yugoslav doctrine as a kind of "static neutrality", passive foreign policy and unwillingness to oppose any serious manifestations of force politics occasionally resorted to by opposing bloc groups. Tito and his associates felt the need to constantly emphasize that Yugoslavia was not a passive neutral, but an active factor in international relations. Therefore, the Yugoslav foreign policy of coexistence is not conciliatory and opportunistic, but creative and dynamic.
} 
huge world reputation, did not feel threatened by the great powers nor did he express any great need to join the Movement in order to suppress their political activities. Namely, he believed that the newly independent states, due to their economic backwardness and political instability, could not play a significant role or achieve a greater reach within international relations. The backbone of Nehru's foreign policy conception was the strategy of maintaining strict equidistance towards the blocs. Tito's initiatives for the gathering and joint action of non-aligned countries were not in the spirit of Nehru's foreign policy strategy, as they could potentially lead to a deterioration in relations with the blocs (Čavoški, 2009, pp. 127-128; 240-242, 257-259; Stojković, 1983, pp. 63-68; DA MSP RS, 1956, PA, 415 765, 416 588; 1957, 395; 1958, 347, 360; 1959, PA, 431 697). With somewhat different political ideals, Egyptian President Nasser was one of the strongest proponents of the concepts of "Arab unification" and "Arab nationalism" in the mid-1950s. As an unifying leader of the Arab world in Africa and Asia, Nasser was guided by different goals that did not coincide with the ideas of creating the Movement of Non-Aligned and Non-Bloc States. Although the unification of Egypt and Syria and then the accession of Yemen, as well as the hint of possible unification with Iraq, were encouraging in that regard, the idea of creating a broad association of nonaligned states was reduced to Nasser's view of the concept of "pan-Arab solidarity" (Bogetić, 2006a, pp. 250-253; Hurani, 2016, pp. 437-439, 479, 490; Stojković, 1983, pp. 68-72; DA MSP RS, 1958, 58, 360; 1960, PA, 435 330; 50, $71,180)$. Ahmed Sukarno and Solomon Bandaranaike, on the other hand, expressed interest in gathering and joint action of states outside the blocs but exclusively on a regional basis by forming a movement of Afro-Asian states in which China would play a crucial role. From this Asian power, they took the position on the inevitability of conflicts between "poor" and "rich nations", "new" and "old forces", "coloured" and "white". Thus, they advocated the concept of the inevitability and permanence of the international class struggle as the only path that leads to the resolution of accumulated international problems and antagonisms. Namely, they believed that peaceful coexistence between developing countries and imperial powers was impossible. The imperial powers will never accept something like that, considering that their main global goal is to use their economic and military superiority, brutally exploit Afro-Asian states and interfere in their internal affairs. Sukarno and Bandaranaike, therefore, highlighted the institutional connection of the new emancipated states as a priority goal, which is being done for the sake of an uncompromising fight against a common enemy - imperialism and colonialism. This class struggle 
was to take place by applying all available means for the purpose of neutralizing them and removing them from the international scene. Ultimately, this concept propagated the use of force as a last resort against an unjust world order based on inequality and the domination of rich countries (Bogetić, 2006b, pp. 221-227; Dimić, Raković, Milošević, 2014, pp. 62-68, 85-88; Tadić, 1968; AJ, KPR, 1959, I-2/11-2; DA MSP RS, 1964, 872).

\section{Tito's vision of the NAM}

Tito knew that without the support of Naser, Nehru, Sukarno and Bandaranaike, it was not possible to form an international movement whose core would be Afro-Asian states. He, therefore, opted for a tactic, popularly called in Yugoslav political circles "step by step" which soon led to the creation of a kind of informal group made up of these countries. At the same time, he forced more and more direct contacts with the officials of these countries. Increasingly frequent meetings with Afro-Asian statesmen soon resulted in the establishment of very cordial and close political and economic relations between Yugoslavia and most of the newly liberated countries in the area. In direct meetings with foreign leaders, the Yugoslav leader carefully and skillfully propagated the political premises of the Yugoslav projection of the new system of international relations. He was aware that international circumstances were increasingly moving in the direction that was in favour of the realization of the Yugoslav foreign policy concept (Bogetić, Dimić, 2013, pp. 15, 23-30, 33-34, 37-51, 56-80; Jovanović, 1985, pp. 48-50; Mates, 1976, pp. 102-113, 117-127). One of the turning points in the institutionalization of cooperation between non-aligned countries was undoubtedly the meeting of the three most influential statesmen - Tito, Nehru and Nasser in Brioni, in July 1956. The significance of this meeting stemmed from the fact that it was the first multilateral meeting of nonaligned countries and that for the first time a multilateral document of nonaligned countries was adopted - the Brioni Declaration (Čavoški, 2009, pp. 86-87; Petrović, 2010, pp. 130-137; Životić, 2008, pp. 74-80). The first initiatives to hold a summit of non-aligned countries came during Tito's overseas tour and a two-month visit to Asia and Africa in the spring of 1961. On that occasion, Tito visited Ghana, Togo, Liberia, Guinea, Mali, Morocco, Tunisia and the United States. In the exchange of opinions with the heads of state of these countries, Tito initiated and developed the idea of establishing closer cooperation, that is, joint actions of non-aligned countries. Although none of these talks openly set out a concrete plan for holding the first non-aligned conference, everything indicated that they were moving 
in that direction. After the end of the tour in Asian and African countries, Tito presented Cairo for the first time with a concrete proposal to convene a broad conference of heads of state and government of non-aligned countries. President Nasser unreservedly approved of Tito's initiative. At the end of the talks, Tito and Nasser agreed to draft the text of a letter sent to non-aligned countries inviting them to Cairo for a preparatory meeting for holding a conference of heads of state or government. Indonesian President Ahmed Sukarno joined the mentioned initiative of Yugoslavia and the UAR, despite the fact that his views on the modalities of joint action of non-aligned countries differed significantly from the strategy advocated by Yugoslav President Tito (Dimić, Raković, Milošević, 2014, pp. 62-68, 8588). ${ }^{3}$ The joint appearance of Tito, Nasser and Sukarno created in a sense an axis - Belgrade-Cairo-Jakarta, which in some way shattered the myth of India's leading role in a non-aligned world and Nehru's inviolable authority in the process of decolonisation and emancipation of new "Third World" countries (Bogetić, 2006a, pp. 342, 361-362). ${ }^{4}$ In a relatively short period, the governments of Ghana and Afghanistan were among the first countries to be invited to attend the preparatory meeting, followed by Prime Minister Nehru (who was also the last of the exposed non-aligned leaders to agree to the idea.). Hence, after a kind of Yugoslav diplomatic offensive, the conditions were provided for the first time in modern diplomatic history to hold a global summit of states that did not belong to any of the existing military-political blocs (Bogetić, 2006a, pp. 349-362; Dimić, Raković, Milošević, 2014, pp. 61-68; AJ, KPR, 1961, I -2/13-7, 8).

\footnotetext{
${ }^{3}$ Sukarno accepted the invitation to hold the First Summit of the Movement of NonAligned Countries in Belgrade as an important stage which would be the introduction and preparation for holding a conference of Afro-Asian countries at which a regional movement would be formed. In that sense, for him, the Belgrade Conference was not a "replacement", but only a "supplement" to the activities in terms of organising such a regional movement.

${ }^{4}$ Until the scheduling of the First Non-Aligned Summit, the Indian Prime Minister persistently opposed holding the meeting, believing that the summit would negatively affect the general situation in international relations and would "only make it harder for the great powers to solve international problems and contribute to easing international tensions." Aware of the extremely negative political implications of political abstinence, he decided, at the last moment, to participate in it.
} 


\section{The Belgrade Conference}

The Belgrade Conference undoubtedly represented a very representative political gathering in which 25 non-aligned countries participated. The conference adopted a declaration that precisely defined the principles and goals of non-aligned politics as an alternative to bloc politics. However, contrary to the prevailing opinion, the Belgrade Conference was not the founding conference of the Non-Aligned Movement. Formally, that Movement was not formed in Belgrade. At the Belgrade Summit, there was a dilemma whether to form institutional mechanisms and bodies that would in the future ensure a continuous and organised joint appearance of non-aligned countries in international relations? Most of the participants in this Summit had a negative attitude on this issue. The most influential Afro-Asian statesmen opposed Tito's initiative, believing that the newly formed movement would take on the characteristics of a "third bloc", which would lead its members to an open confrontation with both the East and the West. In addition, this would seriously complicate relations with the great powers, from which they received extensive economic, financial and military assistance at the time. Supporting Nehru's position - that non-aligned countries by their individual foreign policy orientation create a positive climate in international relations and by their very existence have a positive impact on turbulent international events - most participants in the Belgrade Conference believed that mechanisms for resolving serious world crises were in the hands of great powers. Hence, non-aligned countries should be restrained so as not to unnecessarily complicate the otherwise complex negotiation process. This approach at the Belgrade Conference significantly diminished its contribution to the fight against colonialism and Cold War tendencies. The new gathering of non-aligned countries thus remained in question (Bogetić, Dimić, 2013, pp. 109-122).

\section{Dilemmas in the NAM after the Belgrade Summit}

The increase in the number of countries that have opted for a nonaligned policy with the intensification of the decolonisation process, meanwhile, has become a significant factor in the United Nations voting machinery. In such a changed international situation, there was a new meeting of the heads of state and government of non-aligned countries in Cairo in October 1964. This time, there was no longer any dilemma regarding the expediency of forming the Movement. However, the Summit 
in Cairo imposed a new problem, without the solution of which it was not possible to go further. Namely, at that Cairo Conference, there was a sharp dispute between some participants over the question which countries should be members of that Movement? At the Cairo Summit, the dilemma had to be resolved, whether to accept Tito's concept of universalism or Sukarno's concept of regionalism? Then, should we decide to unite all nonaligned states, regardless of their geographical determination, or go in the direction of forming one regional Afro-Asian movement? As there was no consensus on these issues at the Cairo Conference, there was a stalemate in the regulation of open institutional issues. This crisis manifested itself through the interruption of the continuity of action or more precisely, as a "crisis of non-alignment". (Bogetić, 2017, pp. 101-118). This crisis was overcome only in the middle of 1970, at the Summit of the Non-Aligned in Lusaka (Zambia). At that Summit, which was marked as the "Third Conference of Non-Aligned Countries", an agreement was finally reached on taking concrete measures that would provide the necessary conditions for permanent and synchronized action of non-aligned countries in international relations. In this sense, the Lusaka Summit was also the founding summit of the Non-Aligned Movement. After that Summit, the idea of creating a body or body that would maintain the continuity of joint activities, take care of the implementation of adopted decisions and provide regular consultations, was constantly on the agenda of all major conferences of non-aligned countries. Therefore, after the Third Conference in Lusaka, there was a period that is often called the "golden age" of non-alignment. Such a name seems justified, given that it was a time when there was a sharp branching of institutional mechanisms of cooperation between the non-block countries and their increasingly frequent and increasingly offensive joint action in international relations (Bogetić, 2019, pp. 195-198, 209-211; Tadić, 1976, pp. 225, 238-242; AJ, KPR, I-4-a/9; DA MSP RS, 1970, PA, R, 432 028). In that sense, the formation of the key body of the newly formed movement - the Co-ordinating Bureau - was of special importance. Thus, for the first time in its history, the Non-Aligned Movement gained a kind of executive operational body, which potentially had the opportunity to ensure efficient and coordinated joint action of non-aligned countries, i.e., to implement summit decisions, which were previously reduced to a list of good wishes. Non-aligned countries are becoming more and more capable of reacting together, organised and energetically to sudden changes in the international community that directly endanger their security. Along with the rapid expansion of the area of the political activity of the Non-Aligned Movement and the constant increase in the number of its members, the need for the 
creation of special coordination bodies in the economic, financial and information spheres has become more and more relevant. They are characterized as important levers within the general emancipatory aspirations of Third World countries. The starting point was that the political independence of non-aligned countries was not possible without their economic and financial independence, but also independence within the global system of telecommunications and information (Bogetić, 2014, pp. 165-180; Bogetić, 2019, pp. 317-319). Although the 1970s were undoubtedly the most prosperous period of the Non-Aligned Movement's global engagement, the end of that decade marked the end of such a positive trend. Increasingly sharp disagreements, even armed conflicts among non-aligned countries, manifested between the 1970s and 1980s, were a hint of a serious crisis of the Non-Aligned Movement. The outbreak of the crisis raised the question of whether the actions of the Movement contribute or harm their interests. At the Havana Non-Aligned Summit in September 1979, the host country sought, with the support of a small group of non-aligned countries, to impose its views on the need to radically change the future strategic commitment of the Non-Aligned Movement. Cuba has pledged to tie the Movement to the Eastern Bloc. The curiosity is that the Western media, reporting all the details from the heated debate at the Havana Summit, called this gathering a kind of "boxing match" between the gigantic, bearded Castro and the nailed, barely moving and decrepit Tito, which ended in a convincing victory for the latter. Since Tito died the following year - that was also his last victory on the international political scene (Bogetić, 2019, pp. 397-400, 501-509; Tadić, 1982, pp. 49-51; AJ, KPR, I-4-a/35). After the Non-Aligned Summit in Havana, the Movement faced growing domestic and international challenges. Tito's departure also meant the loss of authority and dynamism of the Movement. Practically, no non-aligned country has tied its destiny to the destiny of the Movement, nor has it considered that the Movement can still be of significant importance to help it realize its key internal and foreign policy priorities. Conflicts between the members of the Movement, which pretended to impose itself as the "conscience of humanity", became more frequent and sharper. At the Summits in New Delhi in 1983 and Harare in 1986, the leaders of some nonaligned states openly expressed the view that the Non-Aligned Movement should be dissolved. It was a serious sign that the time had come to make an objective balance of all domestic and political activities. Critically reviewing the role of the Non-Aligned Movement so far, the member states considered the possibility of continuing earlier actions to address key global issues, such as more efficiently addressing the economic development of 
poor nations in Asia, Africa and Latin America. In this sense, the Movement had to adapt to the new circumstances in the world and redefine the strategy of realizing its priorities and goals (Bogetić, 2019, pp. 530-532; Jazić, 1984, pp. 63-82; Tadić, 1988, pp. 466-475). All this required a turn towards the "three-continental concept", which represented a departure from Tito's idea of universalism.

\section{Reafirmation of the NAM after the Summit in Belgrade in 1989}

The reaffirmation of the Non-Aligned Movement followed at the summit held in Belgrade in September 1989. On the eve of the summit, there were great fears about its success. Yugoslavia took on a difficult role as a key player in designing the Movement's modernization program. The conception of such a program required a gradual liberation from the ballast of ideological exclusivity and one-sided notions of oneself and others. After all, that was the prevailing position which contributed to the Movement being revitalized again and placed on a completely new basis. The new approach also marked the establishment of stronger cooperation with the countries that were involved in the political blocs. This course of the nonaligned was similar to the efforts of the Soviet leader Gorbachev to adapt to the spirit of the time and catch up with it (the so-called Perestroika). Hence, there was more and more talk about the "Perestroika of the Non-Aligned Movement". In "Perestroika", the main priorities were related to the fight to correct the injustices of the existing international economic system, as well as to solving the accumulated economic problems of developing countries. These problems were marked in the declaration from the Belgrade Conference as "much older and much deeper than the Cold War and the bloc confrontation". In that sense, the central place in the concept of modernization of the Movement was occupied by the struggle to bridge the gap between the rich North and the poor South and to eliminate the growing tendency for "the rich to become richer and the poor poorer". At the same time, all components of the reform economic policy in non-aligned countries were elaborated in detail, which were supposed to enable the most successful integration into the world division of labour and world economic flows. Economic issues thus became the main priority of the Movement, which formally confirmed the original principles of non-alignment. The direction of further development of the Movement is contained in the statement of Egyptian President Hosni Mubarak: "that the road should start, but with a changed timetable" (Bogetić, 2019, pp. 531-533; Jakovina, 2011, pp. 621-622; Petković, 1989, pp. 2; Petković, 1995, pp. 86-89). 


\section{Perspective of the NAM - universalism or regionalism}

After the Belgrade Summit, the concept of regionalism prevailed in the Non-Aligned Movement. This was somewhat natural because in the phase of ending the Cold War, Yugoslavia, which advocated universalism, disappeared from the political scene. After its disappearance, other European non-aligned countries such as Malta and Cyprus left the Movement (in 2004). In the recent history of non-alignment, the only European state in the Movement remained the former Soviet republic of Belarus. Today, the term "non-aligned countries" is increasingly giving way to the term "Third World countries" or "developing countries", which indirectly indicates a shift of the Movement's priorities from the East-West issue, towards a much more current preoccupation of international relations in the North-South direction. After the break-up of the SFR Yugoslavia, at the Ministerial Conference of Non-Aligned Countries in Jakarta in 1992, the FR Yugoslavia was deprived of the right to chair the Movement, which had belonged to it until then due to its continuity and the fact that it hosted a previous non-aligned summit. In Jakarta, moreover, the membership of the FR Yugoslavia in the Movement was suspended, thus, officials from Belgrade were prevented from participating in the further work of the Movement. With the regulation of the FR Yugoslavia's membership in the United Nations in 2000, at the meeting of the Co-ordinating Bureau of Non-Aligned Countries in 2001, its request for observer status in the Movement was accepted. It was verified at the ministerial meeting in New York in November 2001. At all subsequent summits of non-aligned countries, the FR Yugoslavia, and then its legal successor, the Republic of Serbia, participated as an observer and were represented at the level of foreign ministers. At the Summit held in Belgrade in 2011, a higher level of cooperation with the Non-Aligned Movement was ensured. The Summit was organised on the occasion of marking the 50th anniversary of the First, Belgrade Conference of Heads of State or Government of non-aligned countries. The fact that non-aligned people accepted the initiative to organise the mentioned jubilee in a country that is not a member of the Non-Aligned Movement, and that Belgrade is the only city in the world that hosted this Movement three times, indicates that our country is still a symbol of non-aligned political option.

\section{References}

Bekić, D. (1988). Jugoslavija u Hladnom ratu [Yugoslavia in the Cold War]. Zagreb, Globus. 
Bogetić, D. (1990). Koreni jugoslovenskog opredeljenja za nesvrstanost [The roots of the Yugoslav commitment to non-alignment]. Beograd, Institut za savremenu istoriju.

Bogetić, D. (2006a). Nova strategija spoljne politike Jugoslavije 1956-1961 [New strategy of foreign policy of Yugoslavia 1956-1961]. Beograd 2006.

Bogetić, D. (2006b). Jugoslovenski koncept nesvrstanosti i afro-azijske zemlje 1945-1961, u: Srbija (Jugoslavija) 1945-2005. Pokreti, ideologije, praksa [Yugoslav concept of non-alignment and Afro-Asian countries 19451961, in: Serbia (Yugoslavia) 1945-2005. Movements, ideologies, practice]. Beograd, Institut za savremenu istoriju.

Bogetić, D. (2012). Jugoslovensko-američki odnosi 1961-1971 [YugoslavAmerican Relations 1961-1971]. Beograd, Institut za savremenu istoriju.

Bogetić, D., Dimić, Lj. (2013) Beogradska konferencija nesvrstanih zemalja. 1-6. septembra 1961. Prilog istoriji Trećeg sveta [Belgrade Conference of NonAligned Countries. 1-6. September 1961. A Contribution to the History of the Third World]. Beograd, Zavod za izdavanje udžbenika.

Bogetić, D. (2014). Jugoslovensko-američke nesuglasice oko koncepta novog međunarodnog ekonomskog poretka [Yugoslav-American disagreements over the concept of a new international economic order]. Istorija XX veka, 32(1), Beograd.

Bogetić, D. (2017). Sukob Titovog koncepta univerzalizma i Sukarnovog koncepta regionalizma na Samitu nesvrstanih u Kairu 1964 [Conflict between Tito's concept of universalism and Sukarno's concept of regionalism at the 1964 Cairo Non-Aligned Summit]. Istorija XX veka, $35(2)$.

Bogetić, D. (2019). Nesvrstanost kroz istoriju - od ideje do pokreta [Nonalignment throughout history - From idea to movement]. Beograd, Zavod za izdavanje udžbenika.

Čavoški, J. (2009). Jugoslavija i kinesko-indijski konflikt 1959-1962 [Yugoslavia and the Sino-Indian conflict 1959-1962 ]. Beograd, Institut za noviju istoriju Srbije.

Dimić, Lj. (2014). Jugoslavija i Hladni rat [Yugoslavia and the Cold War]. Beograd, Arhipelag.

Dimić, Lj, Raković, A, Milošević, M. (2014). Jugoslavija-Indonezija 1945-1967. Prilog istoriji nesvrstanosti, u: Jugoslavija-Indonezija 1945-1967. Istraživanja $i$ dokumenta [Yugoslavia-Indonesia 1945-1967. A contribution to the history of non-alignment, in: Yugoslavia-Indonesia 1945-1967. Research and documents]. Beograd, Arhiv Jugoslavije. 
Gavranov,V, Stojković, M. (1972). Međunarodni odnosi i spoljna politika Jugoslavija [International relations and foreign policy of Yugoslavia]. Beograd, Savremena administracija.

Hurani, A. (2016). Istorija arapskih naroda [History of the Arab peoples]. Beograd, Klio.

Jakovina, T. (2011). Treća strana Hladnog rata [The third side of the Cold War]. Zaprešić, Fraktura.

Jazić, Ž. (1984). Sedma konferencija šefova država ili vlada nesvrstanih zemalja - Nju Delhi od 7. do 12. marta 1983 [Seventh Conference of Heads of State or Government of Non-Aligned Countries - New Delhi from 7 to 12 March 1983]. Godišnjak, Beograd, Institut za međunarodnu politiku i privredu.

Jovanović, J. (1985). Jugoslavija u Ujedinjenim nacijama 1945-1953, Beograd, Institut za savremenu istoriju;

Mates, L. (1972). Međunarodni odnosi socijalističke Jugoslavije [International relations of socialist Yugoslavia]. Beograd, Nolit.

Petković, R. (1985). Nesvrstana Jugoslavija i savremeni svet: spoljna politika Jugoslavije 1945-1985 [Non-aligned Yugoslavia and the modern world: foreign policy of Yugoslavia 1945-1985]. Zagreb, Školska knjiga.

Petković, R. (1989, September 4), Nesvrstani i svrstani, Politika.

Petković, R. (1995). Subjektiona istorija jugoslovenske diplomatije 1943-1991 [Subjective history of Yugoslav diplomacy 1943-1991]. Beograd, Službeni list SRJ.

Petrović, V. (2010). Titova lična diplomatija [Tito's personal diplomacy].Beograd, Institut za savremenu istoriju.

Stojković, M. (1983). Tito-Nehru-Naser - Nastanak i razvoj politike i pokreta nesvrstanosti Tito- diplomatija [Tito-Nehru-Nasser. The emergence and development of politics and the non-alignment movement Titodiplomacy]. Zaječar, RO za grafičko-izdavačku delatnost.

Tadić, B. (1968). Istorijski razvoj politike nesvrstavanja 1946-1966 [Historical development of non-alignment policy 1946-1966]. Beograd, Institut za međunarodnu politiku i privredu.

Tadić, B. (1976). Nesurstanost u teoriji i praksi međunarodnih odnosa [Nonalignment in the theory and practice of international relations].Beograd, Institut za međunarodnu politiku i privredu.

Tadić, B. (1982) Osobenosti i dileme nesvrstanosti [Peculiarities and dilemmas of non-alignment]. Beograd, Izdavački centar Komunist. 
Tadić, B. (1988). Pokret nesvrstanosti - šta činiti posle Hararea, u: Titonesurstanost-savremenost [Non-alignment movement - what to do after Harare, in: Tito-non-alignment-modernity]. Beograd, Memorijalni centar 'Josip Broz Tito'.

Vidić, D. (1988). Značaj XV zasedanja generalne skupštine Ujedinjenih nacija za sazrevanje politike i pokreta nesvrstanosti, u: Tito-nesvrstanostsavremenost [Significance of the XV Session of the United Nations General Assembly for the Maturation of Non-Aligned Politics and Movements, in: Tito-Non-Alignment-Modernity]. Beograd, Memorijalni centar 'Josip Broz Tito'.

Životić, A. (2008). Jugoslavija i Suecka kriza 1956-1957 [Yugoslavia and the Suez Crisis 1956-1957]. Beograd, Institut za noviju istoriju Srbije.

Diplomatski arhiv Ministarstva spoljnih poslova Republike Srbije (DA MSP RS) [Diplomatic archive of the Ministry of Foreign Affairs of the Republic of Serbia]: 1956, PA, f-33, 415765 i 416 588. Indija; 1957, strictly confidental, f-1, 395. Odnosi FNRJ sa Indijom;1958, strictly confidental, f3, 58. Ujedinjenje Egipta o Sirije; strictly confidental, f-3, 325. Jugoslovenskoindijski odnosi u 1956/57. godini; strictly confidental, f-4, 347. Indija. Politički odnosi; f-4, 360. Odnosi Jugoslavije sa nekim zemljama Bliskog istoka i Azije; 1959, PA, f-38, 431 697. Indija; 1960, PA, f-56, 435 330. Međunarodni problemi. Afrika i Bliski istok; strictly confidental, $\mathrm{f}-2,50$, Međuarapski odnosi i politika FNRJ; str. pov, f-2, 71. Ujedinjena Arapska Republika strictly confidental f-2, 180. Velike sile na Srednjem istoku;1964, strictly confidental f-1, 872. 'Nove snage' (Indonežanska inicijativa); 1970, PA, R, f-241, 432028. Dokumentacija za Konferenciju na vrhu u Lusaki.

Arhiv Jugoslavije (AJ) [Archives of Yugoslavia]. Kabinet Predsednika Republike (KPR) [Cabinet of the President of the Republic]: I-2/11-2. Indonezija; I-2/13-7. Zabeleška o razgovorima između delegacije FNRJ $i$ delegacije UAR 20. aprila 1961; Izveštaj Predsednika Republike o putu jugoslovenske delegacije u prijateljske zemlje Zapadne i Severne Afrike, podnet na Sednici Saveznog izvršnog veća, Beograd 29. septembar 1961; I-2/13-8. Zajednicka deklaracija Predsednika Federatione Narodne Republike Jugoslavije Josipa Broza Tita i Predsednika Ujedinjene Arapske Republike Gamala Abdela Nasera; Tekst zajednicke poruke Predsednika Tita i Predsednika Nasera, koja je od 26. aprila nadalje uručena šefovima 21 zemlje; I-4-a/9. Izveštaj o Trećoj konferenciji šefova država ili vlada nesvrstanih zemalja, Lusaka, 8-10. septembar 1970. godine; I-4-a/35. Konferencija šefova država ili vlada nesvrstanih zemalja, Havana, 3-9. septembar 1979. 